\title{
The Effect of E-Commerce Application, User Personality, and Corporative Strategy on the Effectivity of Accountancy Information System and It's Impact on Accountancy Information Quality (Survey on Banking Corporation)
}

\author{
Nasrizal $^{* 1} \quad$ Azhar Susanto $^{2} \quad$ Sri Mulyani $^{3}$ Harry Suharman ${ }^{4}$ \\ 1. Lecturer, Faculty of Economic and Bussiness, University of Riau, \\ Campus Binawidya KM.12,5 Simpang baru, Tampan, Pekanbaru, Riau, Indonesia, 28296 \\ 2. Professor, Faculty of Economic and Bussiness, University of Padjadjaran, Bandung, Indonesia \\ 3. Professor, Faculty of Economic and Bussiness, University of Padjadjaran, Bandung, Indonesia \\ 4. Head Lecturer, Faculty of Economic and Bussiness, University of Padjadjaran, Bandung, Indonesia
}

\begin{abstract}
E-commerce application, personality of users, and corporate strategies are the factors that can improve the effectiveness of accounting information system. Thus, the effectiveness of accounting information system has influence on the quality of accounting information. In Indonesia, this phenomenon happens in many organizations, showing that there is accounting information systems that has not resulted qualified accounting information. This research was carried out in order to find the fact through examination presenting in the influence of e-commerce application, user personality and corporate strategies towards accounting information system which can give impact to the quality of accounting information. Data that is used in this research were gained through survey by distributing questioners to 85 banking companies in Indonesia. The data were then tested statistically by applying SEM-PLS. Research method used was explanatory research. The results of this study showed that the user personality influences the effectiveness of accounting information system and then effectiveness accounting information effect on quality of accounting information, however, for e-commerce application and corporate strategies, there are no significant effect on the effectiveness of accounting information system.
\end{abstract}

Keywords: E-Commerce Application, Personality Users, Corporate Strategies, Accounting Information System Effectiveness and Quality Accounting Information.

DOI: $10.7176 /$ RJFA/10-24-02

Publication date: December $31^{\text {st }} 2019$

\section{Introduction}

Every organization needs good quality information in order to make effective decisions (Romney and Steinbart, 2012: 25). Furthermore, Romney and Steinbart (2012: 25) say that to make effective decisions, organizations must decide what decisions are made, what information is needed and how to collect and process data to produce information. According to McLeod and Schell (2008: 34), the use of information can provide competitive advantages for companies.

The information itself, is defined as the results of data processing that gives meaning and benefits, while data is a fact or anything that can be used as input in producing information (Azhar Susanto, 2013: 38). In accordance with the understanding above, McLeod and Schell (2008:9) suggest that data consists of facts and figures that are usually meaningless and not yet processed, while information is the result of data processing that has meaning, usually tells something that has not been informed to the user. Then according to Hall (2008: 3) information is a business resource. Like other business sources: raw materials, capital, and labor, information is very important and indispensable for the survival of today's business organizations (Hall, 2008:3).

The matter of fact, it was found that, many of the information produced by the company was not of quality, as stated by the Minister of Finance Sri Mulyani (2009). She doubted the quality of data/information provided by Bank Indonesia regarding the bank inspection in Indonesia. Subsequently, Boediono (2010) as Vice President reminded that the Bank must produce a good quality report. He emphasized that a good quality information is very important, banking financial statements must be accurate and not to do window dressing (polishing financial statements) to make it looks good.

Information is generated through information systems (Gelinas and Dull, 2008: 13). Furthermore, Gelinas and Dull (2008:13) say that an information system is a system that consists of a collection of integrated computer-based components and manual components that is created to collect, store and manage data and provide output in the form of information to users. Accounting information system is a special subsystem of information systems that aim to collect, process and report information relating to financial aspects of business activities (Gelinas and Dull, 2008: 14).

In the application of accounting information systems in a company (organization), in reality, it shows that 
there are still various problems. These problems were stated among others by the finance minister of the Republic of Indonesia Sri Mulyani (2008). One of the problems found in the results of the Audit Board of the Republic of Indonesia (Indonesian: Badan PemeriksaKeuangan RI, BPK) examination is that there are differences between the government and BPK on the application of accounting information systems. These differences include the application on the gross or net principle in recognition of oil and gas revenues, the classification of revolving funds and the consolidation of revenues in the Central Government Financial Report (Indonesian: LaporanKeuanganPemerintah Pusat, LKPP). Furthermore, Sri Mulyani said that the Ministry of Finance and BPK need to find a solution as soon as possible to the differences in the realization of the accounting information system that is held in the country's general treasurer with the resulting accounting system held in the state ministry/institution.

The next finding was stated by the chairman of BPK, Anwar Nasution (2008), who stated that transparency and accountability of state financial reports were still low, the quality of ministry reports (state institutions/KL) and regions showed a tendency to deteriorate from year to year. The low of transparency and accountability of the state's financial report, resulting to the opinion given by the BPK on the state's financial financial report as not giving an opinion (disclaimer). The main reason for BPK giving the disclaimer opinion is that the state's accounting information and reporting system is still weak.

The accounting information system itself, is defined as a unified arrangement within the entity, for example a business company that uses physical resources and other components to convert economic data into accounting information, with the aim of satisfying the information needs of various types of users (Wilkinson et al., 2000: 7). Accounting information systems are used as a tool for analyzing decisions or as the decision makers related to corporative transactions (Sri Mulyani NS, 2007: 17). Then according to Gelinas and Dull (2008: 633), an accounting information system is a special subsystem (a specialilzed subsystem) of information systems that collect, process, and report information relating to financial aspects of business activities.

Furthermore, Azhar Susanto (2013: 72) stated the accounting information system is a collection (integration) of sub-systems/components, both physical and non-physical, that are interconnected and work together in harmony to process transaction data which related to the financial problem to become financial information. Subsequently, Romney and Steinbart (2012: 28) define accounting information systems as systems that collect, record, store and process data to provide information for decision makers.

Quality information produced by accounting information systems is a dimension of the effectiveness of the system (Mancini, et al., 2013: 141). Furthermore Mancini et al. (2013: 141) said that an effective accounting information system can be called as the ability of the system to provide information that can be used in accordance with needs. According to Ausenda (2003: 82), effectiveness is how far the program reaches its goals. In line with Fabbris (2006: 2), which defined effectiveness as the level of goal achievement. Furthermore, Gelinas and Dull (2008: 39) stated that effectiveness means that information must be suitable and fully support the needs of users in supporting business processes and user tasks and presented in the right time and format, consistent with the previous format so that it is easy to understand.

Based on the definition above, the understanding of an effective accounting information system can be synthesized as a collection (integration) of sub-systems/components both physical and non-physical that are interconnected and work together in harmony in gathering, recording, storing and processing data to provide information for decision makers.

An effective accounting information system will produce output in the form of quality accounting information (Nofan, 2014). There are five criteria that characterize the quality of information, they are: materiality, relevance, reliability, comparability, and understandability (Bob, 2004: 22). Meanwhile, according to Gelinas and Dull (2008: 20), the quality of information includes: effectiveness, efficiency, confidentiality, integrity, availability, compliance, and reliability. Furthermore Azhar Susanto (2013: 13) revealed that in general accounting information has four dimensions of information quality, namely accurate, relevant, timely and complete.

Based on the results of previous research and developing theories, there are several factors that can influence the effectiveness of accounting information systems that have an impact on the quality of accounting information, such as the use of e-commerce (Deshmukh, 2006: 09; Rama and Jones, 2006: 506; Hurt, 2008: 297), user personality (Block, 2002; Kaluzniacky, 2004: 08; Yogesh et al., 2011: 397) and corporate strategy (Schaltegger, 2008: 436; Romney and Steinbart, 2012: 23; Romney and Steinbart, 2012: 33 ).

The author will explain successively starting with the use of e-commerce. Electronic commerce (ecommerce) application refers to the use of the internet and the web to conduct business transactions (Laudon and Laudon, 2007: 392). E-commerce is part of e-business related to the purchase and sale of goods and services via the internet (Laudon and Laudon, 2007: 67). E-business itself, refers to the use of digital technology and the internet to run major business processes in the company (Laudon and Laudon, 2007: 67). Meanwhile, Hall (2008: 563) stated that e-commerce involves the processing and transmission of data electronically. In addition, Hall (2008: 563) said that this broad definition includes a variety of different activities including: electronic buying 
and selling of goods and services, online delivery of digital products, electronic funds transfer (EFT), electronic trading of stocks, and direct consumers marketing.

Subsequently, Basu (2013) said that e-commerce is a broad concept that includes various commercial transactions that are influenced by media / electronic devices such as facsimile, telex, EDI, internet and telephone.

According to Laudon and Laudon (2007: 404) e-commerce is grouped into three categories, namely: 1) Business to consumer (B2C) which involves the sale of products and services to individual buyers, 2) Business to business (B2B) which involves the sale of goods and services between businesses, 3) Consumer to consumer (C2C) which involves direct sales by consumers to consumers. Whereas McLeod and Schell (2008: 48) mention there are two types of e-commerce that occur with entities outside the corporate boundaries, namely business to consumer (business to consumer / B2C) and business to business (business to business / B2B).

E-commerce application affects the accounting information system as stated by various experts. According to Deshmukh (2006: 9), the influence of e-commerce application on accounting is explained in different terms in the literature. Then Rama and Jones (2006: 506) stated that companies can implement e-commerce applications in their accounting information systems. Through e-commerce, it allows digital commercial transactions between various organizations and each individual (Laudon and Laudon, 2007: 392). Furthermore, Laudon and Laudon (2006: 392) said that commercial transactions of e-commerce involve the exchange of values (for example money) with products or services through organizational and individual boundaries. Based on the explanation above, through e-commerce, accounting information systems can reach customers and suppliers that are far from the physical location of the company.

Based on the results of research Qatawneh (2012: 158) and Ahmad (2013: 1) the application/use of ecommerce affects the accounting information system. Furthermore, Al-Refaee (2012: 1479) from the results of his research, showed that e-commerce applications affect the design of accounting information systems, as well as the application of accounting information systems.

Other factors that can influence the effectiveness of accounting information systems are the personalities of users (Block, 2002, Kaluzniacky, 2004: 8, and Yogesh et al., 2011: 397). Personality is an individual characteristic that explains the consistent patterns of feeling, understanding/awareness (cognition) and behaving (John et al., 2010: 330). Holmann (1997) in Kaluzniacky (2004: 3) defined personality as a person's emotional characteristics and a set of relatively stable behaviors. Similar opinion is also expressed by Ivancevich et al. (2008: 74) which stated that personality is a term used to describe the behavior and feelings of someone.

Support for the theory that stated that the user's personality has the influence on the effectiveness of accounting information systems as stated above, had been proven by Smith's research (1999: 453). The results of his research obtained the evidence that there were effects of various types of personality types on accounting information systems. Subsequently, Dehghanzade (2011), the results of his research indicate that personal characteristics which include openness, agreeableness, conscientiousness, and also job satisfaction, and experience of working with financial software of the users affect the effectiveness of computer-based accounting information systems.

In addition to user personality, corporate strategy is also a factor that can affect the effectiveness of accounting information systems. Romney and Steinbart (2012: 23) stated that accounting information systems and corporate strategies influence one another. Furthermore, Romney and Steinbart (2012: 33) revealed that there are three factors that influence the design/application of accounting information systems namely: development in information technology, corporate strategy and organizational culture. Then, Schaltegger (2008: 436) also stated that the accounting information system requires a redesigned to facilitate the enforcement of corporate strategy.

The influence of corporate strategy on accounting information systems is evidenced by the research conducted by Lawrence (1978: 203). The results of his research stated that the company's strategy together with accounting theory allows for the specification of a good accounting information system design. Likewise, the research conducted by Yolande (1997: 125), from the analysis of data collected through a mail survey of manufacturing companies and financial service companies in North America shows that the orientation of corporate strategy is aligned with information systems strategies that are well modeled through a systems approach.

Based on the phenomena, theories that were used and the results of previous studies, it is necessary to do the research that can provide empirical evidence about the influence of e-commerce application, user personality, and corporate strategies on the effectiveness of accounting information systems and their impact on the quality of accounting information.

\section{Research Method}

Sarantakos (1993: 34) said research methods are methods that are used as tools used by researchers in their research. Whereas Kothari (2004: 8) stated that research methods are all methods or techniques used by 
researchers to solve research problems. Then Phelps et al. (2005: 153) stated the research method determines the tasks to be carried out by researchers in research. The research method used in this study when it is viewed from the purpose of the study, this study belonged into survey research (survey research). And when it is viewed from the type of investigation, this type of research is verificative research and is explanatory research or causal study. This study is included in the hypothesis testing research study which is generally known as experimental studies. In this study the researchers tested the hypothesis of a causal relationship between variables. While viewed from the time horizon of this study included in one shot or cross-sectional studies. In cross-sectional studies, research can be done by collecting data only once, maybe for several days or weeks or months to answer research questions.

Variation operationalization is a process carried out by looking at the dimensions of behavior, aspects, or properties shown through a concept. Furthermore, this concept is translated into elements that can be observed and measured so as to develop a concept measurement index (Sekaran \& Bougie, 2013: 200). According to Kothari (2004: 69), measurement is a relatively complex task mainly related to abstract and qualitative phenomena. With measurement, researchers determine the process of assigning numbers to objects or observations, and the level of measurement becomes a function of the rules in which numbers are set (Kothari, 2004: 69). In operationalizing variables, each of the variables is described in an operational definition.

The operational definitions of each of the research variables are:

1. First variable: The Use of E-Commerce.

The concept of e-commerce application based on theory that can be defined as a broad concept that includes commercial transactions that allow sales and purchases through the Web or appropriate network technology or the use of media/electronic devices such as the internet, facsimile, telex, EDI, and telephone and others. Hereinafter referred to as X1.

Dimensions and indicators used so that the use of e-commerce can be operationalized in a measurement are as follows: Ubiquity, Richness and Interactivity.

2. Second Variable: User Personality

The concept of user personality based on theory can be defined as the personal characteristics of someone who explains the pattern of feeling, thinking, behaving, and cognition that is consistent and stable. Herein after referred to as X2.

Dimensions and indicators used so that the user's personality can be operationalized in a measurement are as follows: Neuroticism, Extraversion/Introversion, Openness/Closeness, Agreeableness/Disagreeableness, Conscientiousness/Inconsiderateness,

3. Third variable: Corporate Strategy

The concept of user strategy companies based on theory can be defined as a pattern of decisions within a company that determines its objectives, which results in policies and plans to achieve those goals. Hereinafter referred to as X3.

Dimensions and indicators used so that the company's strategy can be operationalized in a measurement are as follows: Diversification, Synergy potential, Flexibility.

4. The fourth variable: Effectiveness of Accounting Information Systems

The concept of effectiveness of accounting information systems based on theory can be defined as the ability of information systems to provide accounting information that can meet the needs of users in decision making. Hereinafter referred to as the $\mathrm{Y}$ variable.

Dimensions and indicators used so that the effectiveness of accounting information systems can be operationalized in a measurement are as follows: System quality, System use, User satisfaction, Individual impact and Organizational impact.

\section{Research Results and Discussion}

\subsection{Effect of Use of E-Commerce on the Effectiveness of Accounting Information Systems}

The results of testing the effect of e-commerce application on the effectiveness of accounting information systems show a $\mathrm{p}$ value greater than 0.05 at the $5 \%$ significance level so that it accepts H0. Thus it can be concluded that the data does not provide evidence of the influence of e-commerce application on the effectiveness of accounting information systems. This means that accounting information systems still need strong support from the use of e-commerce applications so that the accounting information systems that are used effectively.

The ineffectiveness of e-commerce application to the effectiveness of accounting information systems at a significance level of 5\% is due to the not yet optimal use of e-commerce applications by banking companies in Indonesia, it can be seen from the reality that (1) the banking companies that were sampled in this study not yet providing various forms of e-commerce (e-banking) applications, this is due to the high investment made related to the use of sophisticated technology and of course it requires careful planning and preparation for its application. In Indonesia, the practice of using e-commerce (internet banking) has only been applied/held by a 
small number of banks, where the bank has used e-commerce (e-banking) at the transactional stage, no longer informational (or just a website) as owned by almost whole bank. In the future, in line with the increasing number of internet users and increasingly intense competition between banks, it is predicted that more banks will provide e-commerce (e-banking) services. (2) the low level of public trust in the e-commerce (e-banking) security system. This is understandable because no matter how sophisticated information technology and computers, can be used by parties who are not responsible for seeking personal gain such as hackers/crackers. Therefore, the use of e-commerce (e-banking) has financial risks for both banks and customers because hackers / crackers are able to penetrate the firewall of a bank's e-banking. The case of a fake website or similar to that of a bank is proof that the security system for the use of e-commerce (e-banking) needs the attention of all parties, especially Bank Indonesia as the bank's supervisory authority. (3) socialization or promotion of e-commerce (ebanking) that has not been evenly distributed to all levels of society, and (4) markets that are limited to the internet user community who are generally the upper middle class and educated (5) users/customers consider that transactions through e-commerce are complicated, which in the end customers are reluctant to make transactions through e-commerce.

\subsection{The Effect of User Personality on the Effectiveness of Accounting Information Systems}

The results of testing the influence of the user's personality on the effectiveness of the accounting information system shows a p value less than 0.05 at the $5 \%$ significance level so that it rejects $\mathrm{H} 0$. Thus, it can be concluded that the data provide evidence of the influence of the user's personality on the effectiveness of the accounting information system. The effect is positive, that is, each user's personality value rises by one standard deviation, then the value of the effectiveness of accounting information systems increases by 0.70 standard deviations of the effectiveness of accounting information systems.

The results of this study provide empirical evidence that the better the personality possessed by the user, the more effective the accounting information system owned by the company. In other words, it can be interpreted that the effectiveness of accounting information systems can be improved if the company can form the best personality possible.

\subsection{The Effect of Corporate Strategy on the Effectiveness of Accounting Information Systems}

The results of testing the influence of the company's strategy on the effectiveness of accounting information systems show a $\mathrm{p}$ value greater than 0.05 at the $5 \%$ significance level so that it accepts $\mathrm{H} 0$. Thus, it can be concluded that the data does not provide evidence of the influence of corporate strategy on the effectiveness of accounting information systems. This means that the effectiveness of accounting information systems still requires a large/strong support from the existence of an appropriate corporate strategy and suitable for the company.

Obtained the results of statistical data processing that does not significantly influence, indicating that respondents' answers to the questionnaire have high variability. The insignificance of the results of this study means that the effect on the sample is not statistically significant, this does not mean that there is no influence of the company's strategy on the effectiveness of the accounting information system.

Currently, with the advancement and development of information technology used, it has changed the business strategy of the banking business world by placing information technology as a major element in the production or service delivery process through the operation of its accounting information system. In addition, the development of information technology has also encouraged the adoption of innovative strategies in the field of banking services.

From the gathered facts, the influence of banking company strategies has not been maximized on the effectiveness of accounting information systems because some banks have not been able to implement banking strategies at a high level. Various forms of strategy in the form of product strategy, price, promotion and location have not yet been optimally applied by most banks. The influence of the corporate strategy that has not been maximized on the effectiveness of accounting information systems indicates that the effectiveness of accounting information systems still requires strong support from the implementation of banking company strategies.

\subsection{The Influence of Effectiveness of Accounting Information Systems on the Quality of Accounting Information} The results of testing the effect of the effectiveness of accounting information systems on the quality of accounting information shows a $\mathrm{p}$ value less than 0.05 at the $5 \%$ significance level so that it rejects $\mathrm{H} 0$. Thus, it can be concluded that the data provide evidence of the effect of the effectiveness of accounting information systems on the quality of accounting information. The effect is positive, that is, each user's personality value rises by one standard deviation, the value of the accounting information system's effectiveness rises by 0.76 the standard deviation of the effectiveness of the accounting information system.

The results of this study provide empirical evidence that the more effective the accounting information system, the more quality accounting information produced by the accounting information system. In other words, 
it can be interpreted that the quality of accounting information can be improved if the company can increase the effectiveness of its accounting information system.

\subsection{Indirect Effects Between Variables}

The results of testing the influence of user personality on the quality of accounting information through the effectiveness of the accounting information system shows a p value of less than 0.05 at the $5 \%$ significance level so that it rejects H0. Thus, it can be concluded that the data provide evidence of the influence of the user's personality on the quality of accounting information through the effectiveness of the accounting information system and its effect is positive. The indirect effect of the user's personality on the quality of accounting information through the effectiveness of accounting information systems is $0.70 \times 0.76=0.53$, at the significance level of 5\%.

User personality influences the effectiveness of accounting information and the effectiveness of accounting information systems influences the quality of accounting information. Therefore, it can be said that if the personality increases, the effectiveness of accounting information systems will also increase, and if the effectiveness of accounting information systems increases, the quality of accounting information will also increase. So if the user's personality increases, the quality of accounting information will also increase).

\section{Conclusions and Suggestions}

\subsection{Conclusion}

Based on the results of the study, it can be concluded as follows:

1. The use of e-commerce has no effect on the effectiveness of accounting information systems.

2. User personality influences the effectiveness of accounting information systems.

3. The corporate strategy has no effect on the effectiveness of accounting information systems.

4. The effectiveness of the accounting information system influences the quality of accounting information.

\subsection{Suggestions}

As for suggestions:

1. Increase the use of e-commerce by:

a) Providing and disseminating various forms of e-commerce (e-banking) applications so that users (buyers) can use/access them according to the desired transaction.

b) Providing e-commerce applications that allow application users to easily make transactions directly through the use of menus available in the application.

c) Providing e-commerce applications (e-banking) at a higher level so that information can be easily changed by application users as needed.

d) Providing reliable security related to the use of e-commerce applications, both concerning payment, delivery of goods and customer data/information security

\section{References}

Ahmad, Muhammad Akram. 2013. Effect of E-Commerce on Accounting Information System, Computerization Process and Cost Productivity. American Journal of Computer Technology and Application. Vol 1, No.1, February.

Al-Hakim, Latif.2007. Challenges of Managing Information Quality in Service Organizations. Idea Group Inc. United Stated.

Al-Rafaee, Khalil Mahmoud. 2012. Effect of E-Commerce on Accounting Information System, Computerization Process and Cost Productivity. American Journal of Applied Sciences.

Anwan Nasution. 2008. AkuntabilitasKeuangan Pemerintah Rendah. Ekonomi. Melalui http://bisniskeuangan.kompas.com

Atabey, Naim Ata, Fatma Ozlem Yilmaz dan Yilmaz, Baki. 2013. An Evaluation Electronic Commerce in Terms of Accouting Information System in the Global Competitive Environment. International Conference on Eurasian Economies.

Ausenda, Giorgio. 2003. On Effectiveness.

Azhar Susanto. 2009. SistemInformasiManajemen: PendekatanTerstrukturResikoPengembangan. Bandung: Lingga Jaya. Lingga Jaya.

Azmi Fitriati dan Sri Mulyani. 2015. Factors that Effect Accounting Information System Success and its Implication on Accounting Information Quality. Asian Journal of Information Technology.

Basu, Subhajit. 2013. Global perspective on E - Commerce taxation law. (e-book)

Block, Jack. 2002. Personality as an Affecto Processing System: Toward an Integrative Theory, New Jersey. 
Bob, Ryan. 2004. Finance and Accounting for Business.

Bodnar, George H. dan Hopwood, William C. 2010. Accounting Informastion Systems. Tenth Edition. Pearson Education, Inc. Publishing- Prentice Hall.

Boediono. 2010. JanganBikinLaporanAneh-Aneh. Nasional. Via http://nasional.kompas.com/read/2010/04.

Brian, Forst dan Manning, Peter K. 1999. The Privatization of Policing: Two Wiews.

Bryan, W. Husted dan Alen, David Bruce. 2010. Corporate Social Stategy: Stakeholder Engagement and Competitive Advantage.

Burch, G. John, Gary Grudnitski. 2012. Information Systems: Theory and Prcatice.

Burger, Jerry M. 2010. Personality. Eighth Edition Wadsworth, Gengega Learning.

Chan, Yolande E., Sid L., Donald W. Barclay, dan Copeland, Duncan G. 1997. Business Strategic Orientation, Information Systems Strategic Orientation, and Strategic Alignment. Information Systems Research. Volume 8 Issue 2. June, pp. 125-150

Charver, Charles S. dan Scheier, Michael F. 2012. Perspective of Personality. Seventh Edition. Pearson Education, Inc.

Cloninger, Susan. 2013. Theories of Personality: Understanding Persons. Sixth Edition. Pearson. Hal. 153

Cohen, Sandra dan Efrosini, Kaimenaki. 2011. Cost accounting systems structure and information quality properties: an empirical analysis. Journal of Applied Accounting Research.

Dehghanzade, Hamed, Mahammad Ali Moradi dan MahvashRaghibi. 2011. A Survey of Human Factors' Impacts on the Effectiveness of Accounting Information Systems, International Journal of Business Administration Vol. 2, No. 4; November 2011. Page.166

Deshmukh, Asuthos. 2006. Digital Accounting: The Effect of The Internet and ERP on Accounting.

Fabbris, Luigi. 2006. Effectiveness of University Education in Italy: Employabiltiy and Competence.

Garrity, Edward J. dan Sanders, G. Laurence. 1998. Information Systems Success Measurement. (online).

Gelinas, Ulric J. dan Dull, Richard B. 2008. Accounting Information System. International Student Edition. Thomson South Western.

Hall, James A. 2008. Accounting Information System. Sixth Edition. South Western: Cengage Learning.

Hansen, Don R. dan Mowen, Maryanne M. 2005. Management Accounting,7th edition, Cincinati-Ohio: South Western Publishing Co.

Hurt, Robert L. 2008. Accounting Information System: Basic Concept \& Current Issues. McGraw Hill.

Ivancevich, John M., Robert Konopaske, dan Michael T. 2008. Organization Behavior and Management, Eight Edition, Mc Graw Hill.

Jackson, Steve, Roby Sawyer dan Greg Jenkins. 2009. Managerial Accounting: A Focus on Ethical Decision Making, Fifth Edition. South-Western Cengage Learning

John, Oliver P, Richard W Robins dan Lawrence A. Pervin. 2010. Handbook of Personality: Theory and Research. (e-book)

Kaluzniacky, Eugene. 2004. Managing Psychological Factors in Information System Work: An Orientation to Emotional Intelligence.

Khosrow, Mehdi Pour. 2001. Managing Information Technology in a Global Economy. Via https://books.google.co.id/books?id

Khosrow, Mehdi Pour. 2004. E-Commerce Security: Advice from Experts. Via https://books.google.co.id/books?id

Kordlouie, Hamidreza; Mohammadi, Faramarz; Naghshineh, Nader; and Tozandejani, Mehdi. 2014. Role of Accounting Conservatism on the Quality of Financial Statements. International Journal of Business and Management.

Kothari, C.R. 2004. Research Methodology Methods and Techniques. Second Revised Edition. New Age International Publisher

Kuhn, Michael dan Remøe, Svend. 2005. Building the European Research Area: Socio-economic Research in Practice. Melalui https://books.google.co.id/books?id.

Laudon, Kenneth C. dan Jane Price Laudon. 2007. Management Information System: Managing The Digital Firm. Tenth Edition. Pearson Education, Inc. New Jersey.

Lawrence, A. Gordon. 1978. Strategic Decision Process and The Design of Accounting Information System: Conceptual Linkages. Accounting, Organiztion and Society, Vol. 3. Issues 3-4.

Lubbe, Sum. 2002. The Economic and Social Impacts of E-Commerce. Idea Group Publishing.

Mancini, Daniela, Vaassen, Eddy H. J. dan Dameri, Renata Paola. 2013. Accounting Information Systems for Decision Making. Springer.

McLeod, Jr. Raymond dan Schell, George P. 2007. Management Information Systems. Tenth edition. Pearson Prentice Hall. New Jersey.

Melewar, T.C. and Jenkins, E. 2002. Defining the corporate identify construct. Corporate Reputation Review, Vol. 5 No. 1, pp. 76-90. 
Mihailovic, Ivan, Ranðelovic, Dragana dan Stojanovic, Dragan. 2010. Accounting Information As Resource For Business Decisioning. Biennial International Congress. Tourism \& Hospitality Industry.

Moscove, Stephen A. 2003. Accounting Information System. John Wiley and Sons. Australia.

Moscove, Stephen A., Simkin, Simon Mark G. dan Bagranoff, Nancy A.1990. Accounting Information Systems: Concept, and practice for effective decision making, fourth edition.

Nash, John F., Chinthia D Heagy. 1993. Accounting Information Systems, third editon

Nicolaou, A. I. 2000. A contingency model of perceived effectiveness in accounting information systems: Organizational coordination \& control effects. International Journal of Accounting Information Systems 1(2): 91-105.

Nofan, Hamid Mohammed Al-Qleemat. 2014. Impact Of Computerized Accounting Information Systems' Effectiveness In Increasing The Efficiency Of Human Capital: Field Study In The Financial Department In The Public Jordanian Universities. Interdiciplinary Journal of Contemporary Research in Business.

Parlakkaya, Raif, 2005. Effects of Electronic Commerce and Accounting Practices. Journal of Economics and Administrative Sciences, Issue 2, Volume: 5 December. page.169-170.

Pervin, Lawrence A. dan John, Oliver P. 2001. Personality: Theory and Research. Eigth Edition. John Wiley \& Sons Inc. Hal. 257

Phelps, Roger P., Ronald H. Sadoff, Edward C. Warburton dan Ferrara, Lawrence. 2005 A Guide to Research in Music Education. Scarecrow Press Inc. USA.

Qatawneh, Adel M. 2012. The Effect of Electronic Commerce on The Accounting Information System of Jordanian Banks, International Business Research.

Rama, Dasaratha V. dan Jones, Frederick L. 2006. Accouting Information System, Internation Student Edition. Thomsom South Western.

Romney, B. Marshall dan Steinbart, Paul J. 2012. Accounting Information Systems, twelfth edition, Pearson Education Limited.

Sajady, Dastgir dan Hashem Nejad. 2008. Evaluation of The Effectiveness of Accounting Inforamtion System. International Journal of Information Science and Technology, Volume 6, No. 2

Sarantakos S. 1993. Social Research. Macmillan Education Australia PTY LTD. South Melboune.

Schaltegger, Stefan. 2008. Environmental Management Accounting for Cleaner Production.

Sekaran, Uma dan Bougie, Roger. 2013. Research Methods for Business: A Skill-Building Approach. Six Edition. John Willey \& Sons Ltd.

Sekulić, Vesna. 2009. Corporate Strategy Development and Competitive Advantage of Enterprise, Economics and Organization. Vol 6. pp. $269-279$.

Smith, Malcolm. 1999. Personality Issues and Their Impact on Accounting and Auditing. Managerial Auditing Journal.

Solichul Huda. 2015. KasusPembobolan Bank MandiriTemukan 3 Modus Kejahatan. Melalui: http://bisnis.news.viva.co.id/news/read/585676-kasus-pembobolan-bank-mandiri-temukan-3-moduskejahatan/2

Sri Mulyani NS. 2009. SistemInformasiManajemen; Analisis dan PerancanganEdisiPertama, Cetakan ke-1, Abdi Sistematika.

Sri Mulyani. 2008. Depkeu dan BPK PerluSehati. Ekonomi. Melalui http://bisniskeuangan.kompas.com

$$
\text { 2009. Sri MulyaniRagukan Data BI. Ekonomi. Melalui }
$$
http://bisniskeuangan.kompas.com/read/2009/09/25

Sugiyono. 2011. MetodePenelitian Pendidikan: PendekatanKuantitatif, Kualititif dan R \& D. Alfabeta, Bandung. SuharsiniArikonto. 2010. ProsedurPenelitian: SuatuPendekatanPraktik, Jakarta, Rineka Jaya.

Suton, C.J. 1980. Economic and corporate strategy.

Thanasankit, Theerasak. 2003. E - Commerce and Cultural Value. (e-book)

Walther, Larry M. dan Skousen, Christopher J. 2009. Using Accounting Information. Online.

Wilkinson, Joseph W., Cerullo, Michael J., Vasant Raval dan Wing, Bernard Wong-On. 2000. Accounting Information Systems: Essential Concepts and Application. Forth edition, John Wiley and Sons, Inc.

Yogesh, Kumar Dwivedi, Micahel R. Wade, Scott L. dan Schneberger. 2011. Information System Theory: Explaining and Predicting Our Digital Society.

Yolande, E. Chan, S.L Huff, Donald W. Barclay dan Duncan G. Copeland. 1997. Business Strategic Orientation, Information System Strategic Orientation, and Strategic Alignment. Information System Research. Vol.8, Issue 2, June. 